\title{
RADOVAN LUKAVSKÝ - PEDAGÓG
}

\author{
ZUZANA SÍLOVÁ
}

Divadelná fakulta Akadémie múzických umení v Prahe

\begin{abstract}
Abstrakt: Pre Radovana Lukavského (1919 - 2008), popredného predstavitela českého moderného herectva, znamenala herecká tvorba výzvu na odhal'ovanie hereckého vnútra a ludských charakterov, so zámerom zušlachtovat' ich, kultivovat' city a vzt’ahy, vzájomné správanie a konanie. Takéto poslanie hereckého umenia presadzoval aj počas svojho pôsobenia na pražskej Akadémii múzických umení a na pražskom Štátnom konzervatóriu. Ako pedagóg sa vždy hlásil k odkazu Konstantina Sergejeviča Stanislavského a vynaložil nemalé úsilie na to, aby myšlienky vel'kého ruského divadelníka bránil pred dobovou vulgarizáciou, ktorá postihla české divadlo na začiatku pätdesiatych rokov 20. storočia. Autorka podáva prehl'ad o základných východiskách jeho pedagogického pôsobenia, ktorým nadviazal na činnost̉ spoluzakladatel’a Akadémie múzických umení Jiř́ho Frejku. Sú obsiahnuté aj v Lukavského odborných publikáciách a štúdiách, ktoré tvoria významný príspevok ku kultivácii umeleckého talentu a súčasne vyjadrujú ucelený vývin podôb a spôsobov herectva v danom historicko-teoretickom kontexte. Klúčové slová: Radovan Lukavský, Akadémia múzických umení Praha, Konstantin Sergejevič Stanislavskij, české divadlo 20. storočia, herecká pedagogika
\end{abstract}

Radovan Lukavský (1919 - 2008) sa - podl’a vlastných slov z lásky k literatúre a poézii - chcel stat’ gymnaziálnym profesorom češtiny a francúzštiny a so študentmi robit divadlo. Jeho úspešné štúdium filológie na Filozofickej fakulte Karlovej univerzity v Prahe prerušili politické udalosti novembra 1939. České riaditel'stvo štátnych dráh zorganizovalo akciu na záchranu vysokoškolákov vystavených možným perzekúciám za účast̉ na spontánnych demonštráciách. Lukavský sa stal tratovým robotníkom, potom ako vyškolený železničný telegrafista v Pečkách d’alej recitoval a viedol dramatický krúžok. Iniciátor a duša všetkých tunajších kultúrnych podujatí však túžil študovat', prihlásil sa teda na dramatické oddelenie pražského konzervatória.

U Anny Iblovej absolvoval školu rozvíjania emocionality recitáciou veršov českých básnikov, u Jiřího Plachého zase školu kondenzácie tejto emocionality do pevne ovládnutých intonačných línií. Spolu s neposedným spolužiakom Jaromírom Pleskotom, ktorému sa tiež málila recitácia básničiek a monológov, si rýchlo našli cestu do Větrníku - divadielka mladých spriaznených duší, ktoré zostali zo zrušenej hereckej školy Emila Františka Buriana po tom, čo umelca deportovali do koncentračného tábora. Od Goldoniho komédie Zvedavé ženy, pre ktorú si konzervatoristi ešte vymýšlali vonkajškovú charakterizáciu (lepili si fúzy a predvádzali prototypy staručkých masiek), hravo preskočili k originálnej klauniáde. Jedno z filmových libriet z Mahenovej Husi na provázku - Stroskotanci v manéži - sa stalo príležitostou konfrontovat’ na miniatúrnom pódiu Větrníku v Topičovom salóne poetizmus slov s mimickým živlom. 
Nadväznost’ na javiskový poetizmus Jiřího Frejku, ktorý v tom čase na konzervatóriu aj vyučoval, i na nespútané herectvo $\mathrm{V}+\mathrm{W}$, ktoré v tridsiatych rokoch mohli mladí obdivovat rovnako ako javiskovú poéziu E. F. Buriana, a na druhej strane komediálne extemporovanie Vlastu Buriana - to všetko sa zapísalo aj do slávneho Mahenovho Nasredina: inscenácie, ktorá v septembri 1945 uvádzala do života legendárnu školskú scénu DISK (skratka z „Divadelní studio konzervatoře“"). Radovan Lukavský hral titulnú postavu múdreho kaddi, „klauna na sudcovskom stolci“.

Pri zrode DISK-u stál Radovan Lukavský spoločne s Jaromírom Pleskotom a profesormi Miroslavom Hallerom a Františkom Trösterom. Umelecky aj finančne mimoriadne úspešná prvá sezóna prakticky dokázala, že plány na založenie vysokej umeleckej školy, Akadémie múzických umení (AMU), ktorými sa už v čase nemeckej okupácie intenzívne zaoberali Frejka a Haller, sú oprávnené a reálne. Rozvíjanie talentových predpokladov a technických schopností sa malo konat' „,v rytme metodickej prípravy“ a „vzájomnej previazanosti“ úloh a vyvrcholit až spoločnou tvorivou prácou na inscenáciách $\mathrm{v}$ divadelnom štúdiu. DISK tak vlastne počas niekollkých rokov suploval vysokoškolský stupeň štúdia, kým sa definitívne stanovili študijné plány vtedy ešte divadelného odboru AMU.

V roku 1946 Jiří Frejka angažoval Radovana Lukavského do Mestského divadla na Vinohradoch (na malé roly, ako vždy dodával Lukavský) a ten sa zároveň vrátil študovat' na univerzitu. Absolvoval všetky predpísané skúšky, ale na záverečné štátnice už neprišiel: zvítazilo divadlo. Medzitým sa sám stal učitel’om.

Konzervatórium si v procese prerodu zo strednej na vysokú školu t’ažko dokázalo udržat’ záujem väčšiny hereckých osobností, ktoré prišli učit’ v porevolučnej eufórii. Riadne miesta boli zaistené len pre niektorých z nich. Radovan Lukavský, ktorého vedúci dramatického oddelenia konzervatória Miroslav Haller hned’ na jeseň 1946 poveril výučbou prvého ročníka, zostal dlhé roky iba externým učitel’om. Vôbec sa to však negatívne neprejavilo na jeho vzt’ahu ku škole či k obsahu výučby. Tým viac, že v prvých rokoch mohol asistovat Jiřímu Plachému, svojmu milovanému profesorovi, ktorý bol jeho vzorom, pri práci na absolventských inscenáciách v DISK-u. K vlastnej učitel'skej činnosti v jednom z rozhovorov povedal: „V tom čase som nebol pedagógom v pravom slova zmysle, ale skôr pomocníkom, skúsenejším kolegom. Nepredstieral som pred triedou, že viem viac, než som v skutočnosti vedel. Otvorene som hovoril, že im môžem len poradit', zoznámit’ ich s vlastnými skúsenost’ami z praxe, upozorňovat' na problémy, s ktorými sa sám stretávam na javisku. “ ${ }^{1}$

Od roku 1950 bol Radovan Lukavský spolu s Karlom Högerom poverený prednášat' hereckú výchovu študentom réžie na Filmovej fakulte Akadémie múzických umení (FAMU). Do roku 1960 tak de facto zabezpečoval prepojenie medzi divadelnou a filmovou fakultou týkajúce sa práce režiséra s hercom, kedže brával študentov z FAMU na svoje herecké hodiny na Divadelnej fakulte Akadémie múzických umení (DAMU). Študenti filmovej réžie tam sledovali prácu študentov herectva, mohli režírovat' niektoré etudy, čo prirodzene viedlo k d’alšej vzájomnej spolupráci na prvých školských filmoch.

Radovan Lukavský napokon pôsobil na FAMU dlhšie než na DAMU, odkial' odišiel v roku 1960. Dôvody, prečo sa nepresadil vo vtedajšom konkurze na riadneho

\footnotetext{
${ }^{1}$ KRATZEROVÁ, H. „O splněném přání“ [rozhovor s Radovanem Lukavským]. In Učitelské noviny, 1983, roč. 33 (86), č. 45, 10. 11. 1983.
} 
pedagóga hlavného predmetu na katedre herectva, boli kádrové a ako vždy aj osobné: jeho úvahy o zmysle výučby a vôbec existencii vysokej umeleckej školy pripadali vedeniu školy privel’mi kritické a nezávislé od toho, čo si žiadala doba.

Lukavský mal pritom za sebou úspešné pôsobenie v Mestských divadlách pražských - v inštitúcii, ktorá vznikla v roku 1950, ked' Jiř́iho Frejku zbavili riaditel'stva Divadla na Vinohradoch a Komorného divadla. Vinohradskú scénu zobrala armáda a Komorné divadlo sa stalo základňou úspešného divadelného konglomerátu riaditel’a Ota Ornesta, ktorý k nemu v nasledujúcich rokoch pripájal d’alšie scény. Radovan Lukavský sa tu popri Rudolfovi Hrušínskom, Václavovi Voskovi a Dane Medřickej stal popredným členom súboru a $\mathrm{v}$ druhej polovici pätdesiatych rokov mimoriadne zaujal publikum i kritiku titulnými rolami v Molièrovom Mizantropovi (1955) či v Nashovom Obchodníkovi s dažd’om (1957). To už ale odchádzal na výzvu Otomara Krejču do činohry Národného divadla, kde ho popri inom čakal Hamlet (1959) - d’alšia z postáv, ktorou sa zapísal do histórie moderného českého herectva. Mimoriadne populárny sa stal i vd’aka filmovej role poručíka Kota v Královi Šumavy (1959) kde navonok striedmymi, ale vnútorne intenzívnymi prostriedkami vytvoril z vedlajšej postavy takmer hlavného hrdinu schematickej predlohy, ktorú režisér Karel Kachyňa s kameramanom Josefom Illíkom a s pomocou d’alších hercov pojali ako rozpálený „,eastern zo života na čiare“. Šest'desiate roky otvorili Lukavskému cestu aj k vytvoreniu významných televíznych rol a sl’ubnú spoluprácu so zahraničnými produkciami.

To všetko ukončuje normalizácia. V roku 1971 bola Radovanovi Lukavskému znemožnená habilitácia na FAMU. Zaslúžilý umelec, stále popredný, ale už menej obsadzovaný člen činohry Národného divadla zostáva externým pedagógom - rovnako ako na pražskom konzervatóriu, kde opät po rokoch vyučuje herectvo. ${ }^{2} \mathrm{Na}$ tamojšom hudobno-dramatickom oddelení pôsobil Radovan Lukavský len osem rokov, lebo zákon v tom čase neumožňoval súbeh viacerých než dvoch zamestnaní. V pedagogickej činnosti dal napokon prednost' FAMU, ktorej zostal verný - rovnako ako činohre Národného divadla - takmer až do posledných chvíl' svojho života.

Jiří Frejka v známej štúdii Divadelná škola už v roku 1945 položil zásadnú otázku: Má byt školou remesla, alebo školou metódy? Staré učenie u „majstra“, odovzdávajúceho adeptovi s arzenálom vlastných remeselných postupov aj vlastné, "hotové" modely či šablóny rol, bolo na novo vznikajúcej vysokej divadelnej škole vystavené kritike. Tá v čase po Februári 1948 poslúžila na spochybňovanie dovtedajších pedagogických postupov, ba čo viac, poslúžila aj úsiliu odstránit’ významné herecké a režisérske autority, ktoré vychádzali z vlastnej praxe a jej reflexie. Podl'a vzoru sovietskych divadelných učilíšt sa vypracúvali osnovy výučby herectva a réžie založené na ideologicky zjednodušenom výklade „metódy Stanislavského“ ako ju interpretoval jeden z jeho žiakov Vasilij Osipovič Toporkov, s dôrazom na tzv. metódu fyzických konaní.

\footnotetext{
${ }^{2} \mathrm{~S}$ prechodom na vysokoškolský model výučby herectva bolo dramatické oddelenie na Štátnom konzervatóriu v Prahe po roku 1948 zrušené. Od konca šest'desiatych rokov naň nadviazalo (vd’aka iniciatíve Oldřicha Nového a dobovej potrebe hercov, ktorí „hovoria, spievajú a tancujú“) hudobno-dramatické oddelenie, kam prišli učit významní absolventi povojnového DISK-u Jiří Vala, Luboš Pistorius, Jaroslava Adamová. V roku 1975 sem pozvali vyučovat aj Radovana Lukavského.

${ }^{3}$ FREJKA, J. Železná doba divadla. Praha : Melantrich, 1945, s. $100-118$.
} 
Jiří Frejka si vtedy poznamenal: „Nebol som pri poslednej redakcii osnov (všetci vraj pracovali). Vyčítal by som im prakticizmus (...) chýba tam to ,ako' - teda naozajstný plán metódy. Preto navrhujem osnovy konkretizovat’ a prepracovat'. Navyše nám v osnovách chýba teoretické východisko, ktoré tam treba vyslovite." ${ }^{4}$ Toporkov podl’a Frejku robí z jednej Stanislavského fázy samoúčelný recept a nie metódu, úplne mimo ponecháva ideovo duchovný obsah metódy a obchádza posledný záujem Stanislavského, ktorý venoval „psychologickej nosnosti slova“. ${ }^{5}$

Frejka svojimi poznámkami márne oponoval stále primitívnejšej ideologizácii a formalistickému výkladu a aplikácii sovietskeho vzoru. Nie je náhoda, že jeho meno nenachádzame ani medzi tými, ktorí s príspevkami vystúpili na konferencii o Stanislavského „systéme“ v októbri 1951, ani na konferencii pedagógov divadelných škôl na tú istú tému, ktorá prebehla o necelý rok neskôr, na prelome augusta a septembra 1952 v Mladej Boleslavi. V tom čase je už Frejka exkomunikovaný zo školy a ostáva mu len niekol'ko týždňov života, ktorý ukončí samovraždou.

Za vlastné pedagogické postupy, zamerané na vonkajšiu hereckú techniku, bol ideologicky uvedomelými mladšími kolegami kritizovaný aj Jiří Plachý (ked’ iní, ako napr. Karel Höger alebo Ladislav Pešek, školu radšej opustili): „A stalo sa, že ho určili na odchod (...), pretože vraj vo svojej výučbe ešte stále neprešiel na Stanislavského metódu“", spomína Radovan Lukavský, ktorý sa ako jediný zastal svojho obdivovaného vzoru, takže vylučovací verdikt sa nakoniec nerealizoval. Avšak Jiří Plachý, rovnako ako Jiří Frejka, len o pár týždňov neskôr sám ukončil svoj život.

Na úsilie svojich predchodcov nadviazal Radovan Lukavský celkom organicky. Podporu pre výučbu, ktorá dáva študentom možnost’ naučit sa mysliet’ integrálne dramaticky, ako hovorieval Jiří Frejka, a harmonicky sa rozvíjat’ v správnej postupnosti a vzájomnej nadväznosti úloh, našiel práve u Stanislavského. Ale nielen uňho. Vlastné skúsenosti z umeleckej praxe konfrontuje s Diderotovými myšlienkami, opiera sa o Zichovu Estetiku dramatického umenia (1931), zamýšla sa nad pojmami, s ktorými prichádza Bertolt Brecht, obracia sa ku Carlovi Gustavovi Jungovi, aj k poznatkom súčasnej psychológie i fonetiky a fyziológie.

Svoje úvahy o problémoch výučby herectva uverejňuje po prvýkrát v roku 1957 na konferencii DAMU s príznačným podtitulom „Ciele a cesty výchovy na našej škole". Hlavný problém je podla neho v rozpoznaní talentu a spôsobe výberu, ktorý by sa nemal spoliehat na subjektívne názory skúšajúcich, ale by mal vychádzat’ zo sústavného skúmania toho, čo vlastne tvorí umelecké (herecké) nadanie, i toho, aké sú jeho ukazovatele. V tejto súvislosti spomína aj d’alšie problémy, medzi ktoré patrí klesajúci počet uchádzačov. V tomto čase sa uvažovalo dokonca o organizovanom nábore, s ktorým Lukavský nesúhlasí. Rovnako ho prekvapuje príznačná črta mnohých adeptov, ktorých pôvodne „priviedol na školu úprimný záujem o divadlo a živelná túžba byt hercom“ a u ktorých dnes cítit” „akúsi pasívnu odovzdanost', či skôr ochotu dat zo seba urobit’ herca, nie sa ním stat". ${ }^{7}$ Celková úroveň uchádzačov sa mu vidí z roka na rok nižšia, podl’a jeho názoru sa stráca kultúra. „Akoby sa strácal estetický

\footnotetext{
${ }^{4}$ Tamže.

${ }^{5}$ Pozri SÍLOVÁ, Z. „Divadelní škola Jiř́ího Frejky: „Myslet integrálně dramaticky'“. In SÍLOVÁ, Z. (ed.) Generace a kontinuita. K českému scénickému umění 20. století. Praha : KANT, 2009, s. 210.

${ }^{6}$ SÍLOVÁ, Z. Radovan Lukavský. Praha :Achát, 1999, s. 89.

${ }^{7}$ Pozri „Čelem k divadelnímu školství" [anketa]. In Divadlo, 1957, roč. 8, č. 5, s. 368.
} 
cit, akoby sa minul zmysel pre krásu. Talentov je stále menej“, konštatuje vo svojom konferenčnom príspevku.

V súvislosti s otázkou, či ide o úpadok alebo o premenu životného pocitu, ktorá je natol'ko podstatná, že nevyhnutne vyvoláva aj premenu v estetickom cítení, naráža Lukavský na problém explicitne reflektovaný v príspevku jeho kolegu, pedagóga činoherného herectva Miloša Nedbala: sú ním pedagógovia hlavného predmetu. Na DAMU k nim v tom čase ešte stále patrili teoretizujúci absolventi moskovského GITIS-u bez vlastnej umeleckej praxe Eva Šmeralová a Vladimír Adámek či niektorí členovia Realistického divadla, ktorí v školských cvičeniach mechanicky aplikovali schematický výklad vybraných pojmov zo Stanislavského. „Hodiny hereckej výchovy“, píše Nedbal, „sú onou tvorivou dielňou, ked’ je ,slovo gestom konané““, a zdôrazňuje, že rovnako prísne, ako škola vyberá študentov, musí vyberat’ aj profesorov, ktorými budú výraznými umeleckými individualitami s umelecko-pedagogickými schopnostami. ${ }^{8}$

„Ak hl’adáme predpoklady pre hereckú tvorbu“, pokračuje Radovan Lukavský, „máme pred očami jej určitú formu. Povedal by som, že jej súčasný stav. Vel’a v ňom už zaostáva. (...) Je samozrejmé, že členovia skúšobnej komisie merajú herecké predpoklady uchádzačov dnešnou predstavou divadla a do vel'kej miery vlastne samými sebou. Napriek tomu im ale nesmie chýbat’ ostražitý zmysel pre to nové, zajtrajšie v tých, ktorých posudzujú. Pre jemné a nezadržatelné premeny v tom, čo ich naozaj citovo vzrušuje, čo skutočne prebúdza ich estetickú l'úbost', teda do čoho sa nemusia, hoci len podvedome, nútit pod vplyvom toho, čo dnes vidia na javiskách. Pre novú mieru vonkajšieho prejavu k vnútornému zážitku. Pre ich subjektívnu pravdivost’. (...) Skutočné umenie ide a pôjde cestou úplnej úprimnosti. Úprimnosti k sebe, k životu, ktorý zobrazuje, aj k lud’om, pre ktorých ho zobrazuje. A umelecký potenciál je priamo úmerný l’udskému obsahu umelca. ${ }^{\text {"9 }}$

Radovan Lukavský teda ako pedagóg presadzoval rovnaké ciele a cesty, akými sa uberal pri vlastnej umeleckej tvorbe. Jeho Hamleta (Národné divadlo Praha, 1959) vnímali kritici a predovšetkým publikum ako muža činu, ktorý prijme svoj osud vypátrat’ a potrestat' vraha vlastného otca - ako aktívny zápas o nastolenie poriadku, ako poslanie tento poriadok bránit aj za cenu vlastného ohrozenia. „Práve sila a odvaha presadzovat' a obhajovat pravdu - to sú struny, ktoré v Hamletovi napäla naša doba ${ }^{\text {10 }}$, napísala Helena Suchařípová s narážkou na odhal'ovanie kultu osobnosti a potrebu vyrovnat’ sa s politickými procesmi začiatku pätdesiatych rokov.

Z Lukavského úvah o hereckej tvorbe, ktoré podla jeho vlastných slov vychádzali z potreby usporiadat' si v hlave aspoň tie najdôležitejšie témy, sa celom prirodzene stali učebnice (hoci by sa ich autor tomuto označeniu možno bránil). Schopnost' plasticky popísat' priebeh kreovania hereckej postavy a dat’ tak nazriet’ do procesu hereckej tvorby, aj jeho úprimná sebareflexia, schopnost' triedit’ a zovšeobecňovat' - to všetko sú príznaky dialógu, o ktorý sa ako herec i pedagóg vždy usiloval, ale na ktorý nie vždy, vlastne skôr málokedy, dostával adekvátnu odozvu.

\footnotetext{
${ }^{8}$ Tamže, s. $363-364$

9 Tamže.

${ }^{10}$ SUCHAŘÍPOVÁ, H. Radovan Lukavský, Praha : Orbis, 1963, s. 29.
} 
Ked’ dnes čítame Denník Hamleta, ktorý vznikal počas skúšok v Národnom divadle, alebo štúdiu Živý priesečník ${ }^{11}$ venovanú dobovej reflexii Stanislavského myšlienok medzi domácimi aj zahraničnými divadelníkmi a predstavujúcu hlboko zasvätený komentár vtedajšej situácie v divadelnej praxi, v škole aj v oblasti teórie, uvedomujeme si, že Lukavského postrehy nestrácajú platnost’ ani po viac než polstoročí, pretože sa dotýkajú samotných základov herectva ako tvorivej a tvoriacej činnosti. Stanislavskij je podla Lukavského zakladatel’om hereckého profesionalizmu a jeho metóda vyplýva logicky z prirodzených zákonitostí tvorby, takže na základe prehĺbeného poznania sa môže d’alej rozvíjat'. Určite nie je náhodou, že v tom istom roku, ked’ sa Stanislavským v časopise Divadlo zaoberá napríklad Alfred Radok, vychádza na Slovensku Lukavského Monológ o herectve ${ }^{12}$. Radovan Lukavský tu pokračuje v zamýšllaní sa nad vlastnými skúsenostami z dovtedajšej hereckej tvorby a opät’ sa vracia k Stanislavskému. ${ }^{13}$

Antiideologické a nedogmatické chápanie a citlivé porozumenie. Táto Stanislavského metóda, ktorá svojím princípom hladania prirodzených, organických podmienok pre slobodný tvorivý akt pomáhala Lukavskému pri vlastnej umeleckej a pedagogickej činnosti, ho o pár rokov neskôr priviedla k spracovaniu zásad Stanislavského systému do prehl'adnej „príručky“, ako sám nazval svoju knižku Stanislavského metóda hereckej práce (1978). Autorka týchto riadkov študovala u Radovana Lukavského na hudobno-dramatickom oddelení pražského konzervatória práve v čase, ked' publikácia vyšla. Môže dosvedčit, že jeho študenti mali možnost' na vlastnej koži zažit proces postupného l’udského aj hereckého sebauvedomovania prostredníctvom praktických cvičení zameraných na jednotlivé prvky metódy. Dopĺn̆al ich výklad príslušných pojmov, takže ich obsah sa stával úplne jasným a zrozumitel’ným. Č́tanie knihy, ktorú študenti dostali do rúk tesne pred záverečnými maturitnými skúškami, bolo potom radostným zistovaním, čo všetko už poznajú - pretože to prežili.

V úvahách o herectve Radovan Lukavský pokračoval pri prepracovaní Monológu o herectve do podoby učebnice pre konzervatóriá. V knihe nazvanej Byt’ a či nebyt' s podtitulom Monológy o herectve (1985) plynule vložil príklady z praxe do historicko-teoretického kontextu, prezentujúc tak ucelený vývin podôb a spôsobov herectva. Paradoxne, práve v tom čase, uprostred osemdesiatych rokov, prestáva učit herectvo na konzervatóriu a s jeho vlastnou metódou výučby sa už môžu zoznamovat' iba študenti réžie na FAMU. Aj tu bol však jeho podiel na predmete zaoberajúcom sa hereckou a hlasovou výchovou, v rámci ktorého sa budúci režiséri zasväcovali do problematiky herectva, od polovice sedemdesiatych rokov oklieštovaný. Preto sa sústredil predovšetkým na predmet Teória herectva a práca režiséra s hercom. Dopíňal ho predmetom Kultúra hovoreného slova - a to aj pre študentov iných katedier FAMU, ktorých záujem o hovorenú podobu materčiny sa usiloval prebúdzat'. Do problematiky ich zasväcoval na základe vlastných, dlhoročných skúseností vynikajúceho interpreta „krásnej reči“, v ktorej silu stále veril: „Kultúra reči je pre nás súčastou životného prostredia, a teda patrí k ekológii ducha! ${ }^{\star 14}$

${ }^{11}$ LUKAVSKÝ, R. „Živý průsečík”. In Divadlo, 1963, roč. 14, č. 5, s. 18 - 28.

${ }^{12}$ LUKAVSKÝ, R. Monológ o herectve. Prel. M. Prídavková-Mináriková. Bratislava : Slovenské vydavatelstvo krásnej literatúry, 1963.

${ }^{13}$ Dvoma fázami povojnového českého záujmu o Stanislavského - socialisticko-realisticky ideologizujúcou a tvorivou - sa zaoberá Jan Hyvnar v štúdii „Stanislavského ,systém” v českém divadle: dogma a inspirace“" ktorú zaradil do svojej knihy O českém dramatickém herectví 20. století. Praha : KANT, 2008, s. 143 - 163.

${ }^{14}$ LUKAVSKÝ, R. Kultura mluveného slova, Praha : Akademie múzických umění v Praze, 2000, s. 7. 


\section{Záver}

Všetko, čím sa Radovan Lukavský v živote zaoberal, bolo naplnené jasným poslaním: zápasom o zachovanie a rozvíjanie kultúry. Herecká tvorba bola preňho výzvou k odhal'ovaniu hereckého vnútra a l'udských charakterov, so zámerom zušlachtovat' ich, kultivovat' city a vzt’ahy, vzájomné správanie a konanie. Jeho pedagogická práca mala popri podporovaní a kultivácii talentu v sebe čosi, čo presahovalo zameranie predmetu štúdia: mravný postoj, ktorý ako pedagóg vštepoval študentom celým svojím vzṫahom k nim a k tomu, čo spoločne robia, aj dôslednost', s ktorou trval na pravidlách vzájomnej spolupráce a na zodpovednosti za ňu. A predovšetkým úsilie pomôct' im, aby porozumeli sami sebe, svojim silným aj slabým stránkam, aby dosiahli naplnenie svojej existencie. Pri všetkej profesionálnej erudícii bol Radovan Lukavský predovšetkým učitel’om pre život.

Z češtiny preložil Miloš Mistrík

\section{EDUCATOR RADOVAN LUKAVSKÝ}

\section{Zuzana SÍLOVÁ}

Radovan Lukavský (1919 - 2008), a prominent representative of Czech modern acting, understood the art of acting as a challenge in revealing an actor's inner world and human characters. His intention was to elevate characters, to refine feelings and relationships, as well as mutual behaviour and action. It was this very mission of the art of acting he promoted during his tenure at the Academy of Performing Arts in Prague and at the Prague State Conservatory. Being an educator, he would unceasingly declare his support for the legacy of Konstantin Sergeyevich Stanislavsky and make considerable efforts to defend the ideas of the great Russian theatre professional from period debasement that infested Czech theatre in the early 1950s. The authoress provides an overview of the fundamental starting points of Radovan Lukavský's pedagogical work, following up on the activities of Jiří Frejka, co-founder of the Academy of Performing Arts. These starting points are also contained in Lukavsky's specialised publications and studies capturing the development of the forms and methods of acting in a given historical and theoretical context.

Štúdia je príspevkom k projektu APVV č. 15-0764 Slovenské divadlo a súčasná európska divadelná kultúra - kontinuita a diskontinuita.

\section{LITERATÚRA}

„Čelem k divadelnímu školství“ [anketa]. In Divadlo, 1957, roč. 8, č. 5, s. 353 - 385.

FREJKA, Jiř́i. Železná doba divadla. Praha : Melantrich, 1945. $136 \mathrm{s.}$

HYVNAR, Jan. O českém dramatickém herectoí 20. století. Praha : KANT, 2008. 324 s. ISBN 97880-86970-63-9. 
KRATZEROVÁ, H. „O nesplněném přáni“ [rozhovor s Radovanem Lukavským]. In Učitelské noviny, 1983, roč. 33 (86), č. 45, 10. 11. 1983. ISSN 0139-5718.

LUKAVSKÝ, Radovan. „Živý průsečík“. In Divadlo, 1963, roč. 14, č. 5, s. 18 - 28.

LUKAVSKÝ, Radovan. Monológ o herectve. Bratislava : Slovenské vydavatel'stvo krásnej literatúry, 1963. $189 \mathrm{~s}$.

LUKAVSKÝ, Radovan. Stanislavského metoda herecké práce. Praha : Státní pedagogické nakladatelství, 1978. $155 \mathrm{~s}$.

LUKAVSKÝ, Radovan. Být nebo nebýt. Monology o herectví. Praha : Státní pedagogické nakladatelství, 1985. $246 \mathrm{~s}$.

LUKAVSKÝ, Radovan. Zpráva o výuce herectví při studiu filmové režie. [Habilitačná prednáška prednesená 20. 4. 1993.] In Acta Academica '93: bulletin pro teoretickou a védeckou činnost AMU. Praha : Akademie múzických umění v Praze, 1996. 138 s. ISBN 80-85883-12-0.

LUKAVSKÝ, Radovan. Kultura mluveného slova. Praha : Akademie múzických umění, 2000. 105 s. ISBN 80-85883-61-9.

SÍLOVÁ, Zuzana. Radovan Lukavský. Praha : Achát, 1999. 293 s. ISBN 80-90222-19-6.

SÍlOVÁ, Zuzana (ed.). Generace a kontinuita. K českému scénickému umění 20. století. Praha : KANT, 2009. 240 s. ISBN 9788074370106.

Stenografický zápis pedagogickej konferencie divadelnej fakulty AMU konanej dňa 14. a 15. apríla 1957 v Prahe. Strojopis uložený v knižnici DAMU.

SUCHǍ̌IIPOVÁ, Helena. Radovan Lukavský. Praha : Orbis, 1963. 76 s.

\author{
Zuzana Sílová \\ Divadelní fakulta AMU \\ Karlova 26 \\ 11665 Praha \\ Česká republika \\ e-mail: zuzana.silova@damu.cz
}

